\title{
Efektivitas Buku Siswa IPA Terpadu dengan Tema Energi dalam Kehidupan berbasis Materi Lokal Menggunakan Model Integrated untuk Meningkatkan Kecakapan Abad 21
}

\author{
Zaitul Hidayat, Rahima Syabrina Sarmi, Ratnawulan* \\ ${ }^{1)}$ Magister Pendidikan Fisika, FMIPA, Universitas Negeri Padang \\ *ratnawulan@fmipa.unp.ac.id
}

\begin{abstract}
The current science student book is expected to have learning and assessment in it that is relevant to the demands of education now that is in accordance with $21^{\text {st }}$ century learning that contains is critical and problem solving skills, creativity and innovation skills, collaboration skills, and communication skills it aims to develop the potential, talents and interests of students to have competent student who are ready to face global challenges. This article aims to evaluate the science student book with the theme of energy in life based integrated local materials using integrated models $21^{\text {st }}$ century learning. Evaluation consists of testing the effectiveness of $21^{\text {st }}$ century learning student's skill after using this science student book. Thus, the results of study indicate that science student book with the theme of energy in life based integrated local materials using integrated models $21^{\text {st }}$ century learning which is effectively used in student learning in class. Based on these result, it appears that science student book with the theme of energy in life based integrated local materials using integrated models can improve student's High Order Thinking Skill (HOTS).
\end{abstract}

Keywords :Effectiveness, Science Student's Book, Local Based Material, 21st Century Learning

\section{PENDAHULUAN}

Pengembangan pendidikan belum mampu memiliki kecepatan yang sama dengan teknologi sekarang yang terus berkembang. Saat ini, pendidikan dituntut untuk mengaplikasikan berbagai keterampilan kedalam pembelajaran guna untuk membantu meningkatkan berbagai kecekapan yang dimiliki siswa. Sumber belajar merupakan faktor utama yang dapat mendukung untuk mengoptimalkan kecakapan-kecakapan yang dimiliki oleh peserta didik salah satunya adalah buku siswa (Hidayat \& Ratnawulan, 2019). Buku siswa yang digunakan di sekolah masih belum optimal pembuatan dan penggunaannya. Berdasarkan analisis awal akhir, sumber belajar belum memudahkan peserta didik dalam memahami pembelajaran IPA di sekolah. Berda sarkan analisis peserta didik, peserta didik menyukai pelajaran yang bersifat nyata dalam kehidupan sehari-hari, peserta didik lebih semangat jika pelajarannya dihubungkan dengan kehidupan sehari-hari, pelajaran yang dimulai dari fakta atau kenyataan membuat peserta didik mudah menghubungkan nya dalam pembela jaran. Berdasarkan analisis buku siswa, tidak memiliki identitas materi, tidak terdapat peta konsep didalam buku siswa, belum terikat dengan sebuah tema yang membantu memadu kan beberapa mata pelajaran menjadi satu, dan belum berbasis materi lokal daerah setempat peserta didik guna membantu menambah wawasan peserta didik. Serta buku siswa belum terintegrasi pembelajaran abad 21 yaitu keteram pilan 4C. Oleh karena itu tujuan pembelajaran IPA Terpadu akan sulit dicapai.

Buku Siswa merupakan buku teks Pelajaran disusun berdasarkan KI dan KD setiap tingkatan sekolah memiliki karakteristik dari berbagai mata pelajaran. Buku teks di sekolah memiliki 2 buku yaitu buku siswa dan buku guru yang harus digunakan dalam proses pembelajaran. Dalam menyusun suatu Buku siswa ini, penulis akan mencantumkan KI dan KD berdasarkan dokumen Kompetens Inti dan Kompetensi Dasar Kurikulum 2013.

Materi pembelajaran IPA Terpadu nanti nya mampu menjawab tantangan tersebut. Materi pembelajaran dihubungkan dengan fenomena-fenomena dan fakta yang terjadi disekitar peserta didik atau pembelajaran yang bersifat faktual yang berbasis materi lokal dimana peserta didik melakukan proses pembelajaran, guna membantu memahami dan meningkatkan keterampilan abad 21. Materi pembelajaran akan bermakna jika dihubungkan dengan kehidupan sehari-hari siswa atau materi 
lokal di sekitar siswa. Materi Lokal adalah pandangan hidup dan ilmu pengetahuan serta berbagai strategi kehidupan yang berwujud aktivitas yang dilakukan oleh masyarakat lokal dalam menjawab berbagai masalah dalam pemenuhan kebutuhan mereka. Materi Lokal dikonsepsikan sebagai kebijakan setem pat atau pengetahuan setempat "local know ledge" atau kecerdasan setempat local genious (Fajarini, 2014). Berbagai strategi dilakukan oleh masyarakat setempat untuk menjaga kebudaya annya. Hal senada juga diungkapkan oleh Alfian (2013). Materi lokal diartikan sebagai pandang an hidup dan pengetahuan serta sebagai strategi kehi dupan yang berwujud aktifitas yang dilakukan oleh masyarakat lokal dalam memenuhi kebutuhan mereka.

Pembelajaran terpadu adalah pembe lajaran dengan tema tertentu untuk mengaitkan antar disiplin ilmu dengan mengaitkan kedalam kehidupan sehari-hari (Kadir, 2014). Dalam pembelajaran IPA dapat dilakukan dengan berbagai macam model keterpaduan. Sejumlah model pembelajaran terpadu, tiga diantaranya sesuai untuk dikem bangkan dalam pembela jaran IPA tingkat pendidikan di Indonesia. Ketiga model yang dimaksud adalah model keterhubungan (connected), model jaring labalaba (webbed), dan model keterpaduan (integrated) (Fogarty, 1991).

Pembelajaran IPA Terpadu saat ini perlu memadukan paradigma-paradigma ilmiah tentang istilah sains dan gejala- gejala alam yang terjadi disekitar kehidupan peserta didik. Latar belakang aktivitas dan materi lokal disekitar perserta didik menjadi factor utama dalam mempengaruhi berhasil atau tidaknya proses belajar mengajar di sekolah. Pengetahuan kon septual peserta didik dibentuk berdasarkan pengalamannya melalui pengetahuan yang diwa riskan secara turun-menurun. Oleh karena itu, dengan adanya lingkungan sosial budaya yang baik sangat perlu menjadi pertimbangan dan perhatian dalam mengembangkan dan menja lankan proses belajar IPA Terpadu di sekolah.

Berdasarkan penilaian terhadap keteram pilan abad 21 peserta didik di Sekolah Menengah Pertama di Sijunjung, Sumatera Barat pada tahun pelajaran 2018/2019 didapat bahwa keterampilan abad 21 peserta didik masih rendah. Persentase ketuntasan peserta didik pada pembelajaran IPA juga cukup rendah yaitu dibawah $60 \%$. Hasil observasi yang dilakukan di Sekolah Menengah Pertama di daerah Sijunjung,
Sumatera Barat menunjukkan bahwa proses pembelajaran lebih terfokus pada pembelajaran yang meminta peserta didik untuk memahami materi pelajaran dengan cara mendengarkan penjelasan dari guru (teacher centered), dan membaca buku atau sumber belajar yang disediakan di sekolah. Serta disekolah belum menilai dan menerapkan keterampilan siswa, yaitu keterampilan 4C (Keterampilan berpikir kritis dan pemecahan masalah, kreatif dan inovatif, berkomunikasi serta kolaborasi). Pelaksanaan pembelajaran IPA Terpadu belum terlaksana dengan maksimal, hal ini dikarenakan pentingnya buku siswa dalam pembelajaran belum menjadi perhatian serius dalam pembelajaran. Buku siswa ini nantinya akan menjadi bahan pembelajaran bagi peserta didik sehingga dapat membantu peserta didik dalam memahami konsep IPA. Buku siswa memiliki beberapa keunggulan yaitu terdapat banyak informasi aspek pengetahuan, aspek sikap siswa, dan keterampilan siswa untuk pencapaian kompetensi peserta didik (Prastowo, 2013).

Oleh karena itu, perlu mengembangkan buku siswa yang layak ditinjau dari isi, konstruk, kebahasaan, dan kegrafikan. Hasil preliminary research menunjukkan bahwa buku siswa yang digunakan dalam pembelajaran belum sesuai dengan harapan. Buku siswa yang diharapkan memiliki bahasa yang sederhana dan mudah dipahami, sesuai dengan saintifik, serta mencakup keterampilan-keterampilan abad 21 dan sesuia dengan tuntunan pendidikan nasional saat ini yaitu untuk meningkatkan keterampilan abad 21 guna untuk menjawab tantangan global.

Buku siswa yang dikembangkan disaran memehami beberapa konsep dalam pengem bangannya dimulai dengan bagian penghantar dari masing-masing bab, membuat kegiatan-ke giatan pembelajaran, kegiatan diskusi dan mem verifikasi hasil diskusi dengan informasi konsep yang diberikan (Tim Pengembang Materi Bimbingan Teknis Kurikulum 2013 SMP, 2018)

Hasil observasi menunjukkan bahwa pelaksanaan pembelajaran IPA Terpadu masih belum terlaksana dengan baik karena masih banyak kendala yang dihadapi baik dari guru, peserta didik maupun dari sumber belajar yang digunakan. Kemudian berdasarkan penelitian terdahulu tentang pengembangan buku siswa IPA itu masih memiliki keterbatasan dan kekurangan. Tujuan penelitian ini adalah untuk mengembangkan dan mengevaluasi buku siswa 
IPA Terpadu berbasis materi lokal yang telah dikembangkan.

\section{METODE PENELITIAN}

Jenis penenelitian ini adalah penelitian pengembangan (Research \& Development) dan model pengembangan yang digunakan adalah Model Plomp. Model Plomp terdiri atas tiga tahap, yaitu: 1) Preliminary Research (analisis pendahuluan berupa analisis kebutuhan dan konsep), 2) Prototyping Phase (tahap peran cangan yaitu desaign, develop dan evaluasi formatif), 3) Assesessment Phase (tahap evaluasi semi sumatif).

Prosedur pengembangan penelitian di awali dengan perencanaan Buku Siswa yang akan dibuat pada pembelajaran IPA dengan tema energi dalam kehidupan berbasis materi lokal daerah Sijunjung menggunakan model IPA terpadu tipe Integrated dikembangkan dengan model Plomp. Masing-masing tahap tersebut dijelaskan pada Tabel 1 .

Tabel 1. Kriteria Evaluasi Dalam Setiap Tahap Pengembangan

\begin{tabular}{|c|c|c|}
\hline Fase & Kriteria & Deskripsi Aktifitas \\
\hline $\begin{array}{l}\text { Prelimi } \\
\text { narv }\end{array}$ & Penekanan ter & Analisis masalah \\
\hline Research & vali ditas isi, & tur (masa lalu atau \\
\hline & tidak banyak & \\
\hline & konsis & dalam sebuah ke \\
\hline & tensi dan & rangka untuk inter \\
\hline & kepraktisan & vensi \\
\hline
\end{tabular}

Prototy Awalnya: Protomodel yang ping konsistensi (val akan diujicoba kan Phase ditas konstruk) dan direvisi berda dan praktika sarkan eva luasi litas, ke mudian formatif Proto menguta makan model awal hanya praktikalitas berbasis lembar dan secara ber evaluasi formatif tahap menuju yang dilakukan me pada efektivitas lalui penilaian ahli yang menghasilkan ke praktisan yang di harapkan

\begin{tabular}{lllr}
\hline Assesss & Praktikalitas & Menilai apakah \\
ment & dan & pengguna dapat \\
Phase & efektivitas & bekerja dengan \\
& & produk yang te \\
& & lah dibuat dan \\
& bisa diterapkan da \\
& & lam pembela jaran \\
\hline
\end{tabular}

\begin{tabular}{|c|c|c|}
\hline Fase & Kriteria & Deskripsi Aktifitas \\
\hline & & $\begin{array}{l}\text { (relevan dan ber } \\
\text { kelanjutan), dan } \\
\text { apakah produk } \\
\text { yang te lah dibuat } \\
\text { itu efektif }\end{array}$ \\
\hline
\end{tabular}

Sumber: Plomp (2013)

Subjek uji coba pada pengembangan buku siswa IPA terpadu ini adalah peserta didik kelas VII SMP Negeri 1 Sijunjung. Selanjutnya KD terdapat pada Kompetensi Dasar 3.6 : Meng analisis konsep energi, berba gai sumber energi, dan perubahan bentuk energi dalam kehidupan sehari-hari termasuk foto sintesis. 3.7 Meng analisis interaksi antara makhluk hidup dan lingkungannya serta dinamika populasi akibat interaksi tersebut. 3.8. Menganalisis perubahan Iklim dan dambaknya bagi ekosistem.

Kriteria untuk efektivitas dari buku siswa menggunakan penilaian keterampilan $4 \mathrm{C}$ yaitu keterampilan berpikir kritis, kreatif dan inovatif, berkolaborasi serta keterampilan berkomunikasi yang masing-masing terdiri dari rubrik penilaian dan pendoman penskoran. Analisis data dilaku kan pada lembar efektivitas. Teknik analisis data menggunakan skala Likert.

Menurut Sugiyono (2011) skala Likert digunakan untuk mengukur sikap, persepsi dan pendapat seseorang atau sekelompok orang terhadap potensi dan permasalahan suatu objek, rancangan suatu produk, proses membuat produk dan produk yang telah dikembangkan. Menurut Arikunto (2010) skala Likert disusun dalam lima respon yang dibentuk berdasarkan suatu pernyataan untuk menunjukkan sebuah peningkatan.

Analisis efektifitas menggunakan teknik data yaitu teknik persentase. Dimana efektifitas dari buku siswa ini dinilai menggunakan angket dari efektifitas yang dirancang untuk semua penilaian keterampilan abad 21 yang terdiri dari (1) Keterampilan berpikir kritis dan pemecahan masalah, (2) Keterampilan berkomunikasi, (3) Keterampilan kreatif dan inovatif, (4) Keterampilan kolaborasi.

Kategori efektifitas dari Buku Siswa ini bisa dilihat pada Tabel 2 .

Tabel 2. Kategori Kefektifan dari Buku Siswa

\begin{tabular}{ll}
\hline Interval $(\%)$ & Kategori Efektif \\
\hline $0-20$ & Tidak Efektif \\
$21-40$ & Kurang Efektif
\end{tabular}




\begin{tabular}{ll}
$41-60$ & Cukup Efektif \\
$61-80$ & Efektif \\
$81-100$ & Sangat Efektif \\
\hline
\end{tabular}

Sumber : Dimodifikasi dari Riduwan(2009)

Berdasarkan Tabel 2 bahwa buku siswa yang dikembangkan akan efektif jika telah memiliki skor dengan rentang interval 61-80.

Keterampilan abad 21 peserta didik dikategorikan baik apabila telah mencapai KKM pada kompetensi pengetahuan yang telah ditetap kan oleh masing-masing satuan pendidikan. Analisis kompetensi pengetahuan dapat menggunakan persamaan:

$$
\begin{aligned}
& K I=\frac{S B}{S M} x 100 \% \\
& K K=\frac{J T}{J S} x 100 \%
\end{aligned}
$$

Keterangan:

KI : ketuntasan siswa per individu

SB : skor benar siswa

SM : skor maksimum

KK : ketuntasan klasikal

JT : jumlah yang tuntas

JS : jumlah keseluruhan peserta didik

\section{HASIL DAN PEMBAHASAN}

Pengujian efektifitas buku siswa IPA terpadu yang dikembangkan dilakukan oleh 34 siswa di SMP Negeri 1 Sijunjung. Sebelum dilakukan efektivitas, dilakukan terlebih dahulu valid dan praktikalitas dari buku yang diteliti. Untuk melihat kepraktisan dari buku ini dilakukan beberapa langkah.

Ada lima langkah dalam praktikalitas yang dilakukan pada peneltian buku siswa IPA terpadu ini yaitu : 1) panduan obyektif dan pengguna yang menjelaskan kepada guru dan siswa; 2) setelah buku siswa IPA Terpadu diperkenalkan, siswa diminta untuk berkola borasi dalam kelompok diskusi mereka; 3) dalam kelompok-kelompok siswa belajar dengan metode diskusi, menggunakan buku siswa IPA Terpadu berbasis materi lokal dan difasilitasi oleh guru; 4) guru mengamati siswa untuk melihat kesulitan mereka; dan 5) siswa diminta untuk menyelesaikan kuesioner kepraktisan. Dengan demikian, buku siswa IPA Terpaadu tipe Integrated berbasis materi lokal untuk meningkatkan kecakapan abad 21 direvisi sesuai dengan hasil kepraktisan (Hidayat, 2019).

Tiga puluh empat siswa kelas satu SMP Negeri 1 Sijunjung yang terlibat dalam pengujian kepraktisan untuk buku siswa dan juga terlibat dalam pengujian efektivitas. Selain itu, pengujian efektivitas selesai pada waktu yang sama dengan pengujian pada kepraktisan, menggunakan bahan yang sama buku siswa IPA Terpadu berbasis materi lokal. Instrumen yang digunakan selama pengujian efektivitas adalah rubrik ketermpilan abad 21 yang terdiri dari penilaian keterampilan berpikir kritis, penilaian keterampilan kreatif dan inovasi, penilaian keterampilan berkomunikasi dan penilaian keterampilan kolaborasi, serta dilakukan setelah siswa menyelesaikan pelajaran mereka meng gunakan buku siswa IPA Terpadu. Kemudian juga dilakukan essay test yang dilakukan untuk setiap kegiatan. Setelah itu, jawaban siswa dianalisis menggunakan rubric keterampilan abad 21. Contoh rubric keterampilan abad 21 disajikan pada Gambar 1. Setelah skor siswa diperoleh untuk setiap indikator didasarkan pada rubric keterampilan abad 21, skor dikonversi menjadi persentase. Persentase ini mewakili pencapaian kemampuan dari keterampilan abad siswa untuk setiap proses pembelajaran.
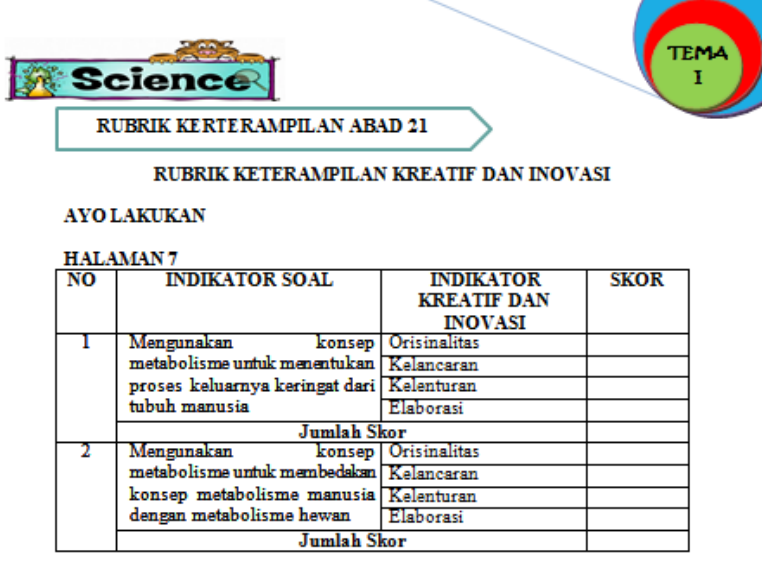

RUBRIK KETERAMPILAN BERKOMUNIKASI

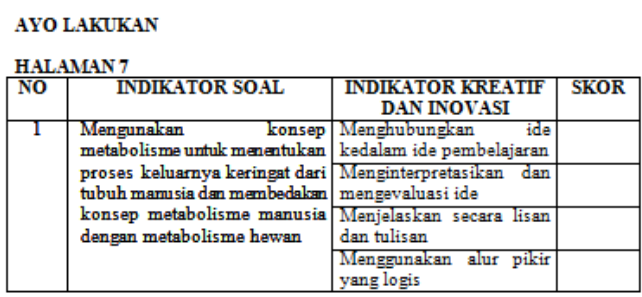

untuk SMP/MTS Kelas VII

ZAITUL HIDAYAT

Gambar 1. Contoh Rubrik Penilaian Keteram pilan Abad 21 pada Buku Siswa

Efektivitas buku siswa dilihat berdasarkan hasil angket dari indikator-indikator pada satu kelas. Dilakukan 2 perlakukan dalam satu kelas yaitu sebelum dan sesudah melakukan perla kuan. Untuk melihat keefektifan buku siswa tersebut dilihat apakah terjadi peningkatan keterampilan 4C pada peserta didik. Untuk kete rampilan $4 \mathrm{C}$ ada 4 paramater yaitu keterampilan 
berpikir kritis dan pemecahan masalah, kreatif dan inovatif, berkomunikasi dan keterampilan kolaborasi.

Keterampilan berpikir kritis dan peme cahan masalah dinilai pada setiap per temuan. Berdasarkan Gambar 2, terjadi pening katan keterampilan berpikir kritis dan pemeca han masalah pada setiap pertemuan. Hal ini disebabkan, karena buku siswa IPA Terpadu tipe integrated dengan tema energi dalam kehidupan berbasis materi lokal untuk meningkatkan keterampilan abad 21 berisikan materi berbasis materilokal dengan penguatan adanya soal dan kegiatan siswa, sehingga peserta didik terlatih dan membantu meningkatkan keterampilan berpikir kritis.

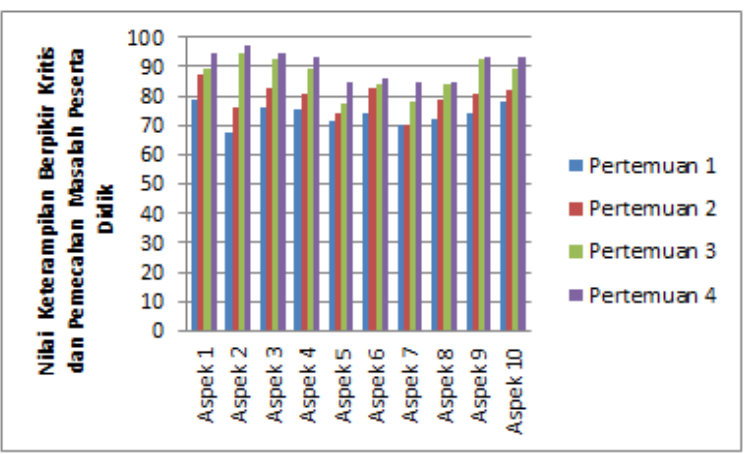

Gambar 2. Rekapitulasi Hasil Penilaian Kete rampilan Berpikir Kritis dan Pemeca han Masalah Peserta Didik Setiap Pertemuan

Keterangan : Aspek 1 : Merumuskan pertanya an; Aspek 2 : Mengidentifikasi kriteria untuk mempertim bangkan jawaban; Aspek 3 : Berpen dapat sesuai dengan sumber yang tepat; Aspek 4 : Mampu memberikan alasan yang tepat dalam menyanggah; Aspek 5 : Menjawab perta nyaan klarifikasi dan pertanyaan yang menantang; Aspek 6 : Menyimpulkan materi yang dibahas; Aspek 7 : Mendefinisikan masa lah; Aspek 8 : Memutus kan hal-hal yang akan dilakukan; Aspek 9 : Mampu berstrategi logika; Aspek 10 : Mampu bekerjasama dengan siswa lain.

Rata-rata penilaian keterampilan berpikir kritis dan pemecahan masalah yang diperoleh peserta didik untuk setiap pertemuan dalam kategori baik yaitu pada saat dilakukan pertemuan 1, pertemuan 2, pertemuan 3 dan pada pertemuan ke-4 berada dalam kategori sangat baik. Setelah ujicoba dilakukan nampak bahwa nilai penilaian keterampilan berpikir kritis dan pemecahan masalah mengalami kenaikan dari pertemuan pertama sampai pertemuan terakhir. Hal ini berarti rata-rata keterampilan berpikir kritis dan pemecahan masalah yang dimiliki peserta didik setelah belajar menggunakan buku siswa sudah baik. Artinya setelah melakukan pembelajaran dengan buku siswa, peserta didik rata-rata baik dalam melakukan kegiatan dalam pembelajaran. Dan menambah pengetahuan peserta didik, karena buku siswa yang dibuat berbasis materi lokal daerah tempat peserta didik berada.

Materi lokal yang disajikan pada buku siswa adalah materi lokal yang berada pada dae rah Sijunjung, Kabupaten Sijunjung, Sumatera Barat. Materi lokal yang ambil berupa kaarifan lokal daerah dari daerah tersebut. Mulai dari kegiatan masyarakat, makanan, tempat wisata sampai bencana yang ada kemudian dimasukkan kedalam Buku Siswa IPA Terpadu tipe integrated agar pembelajaran peserta didik lebih bermakna, karena pembelajaran terkait dengan kehidupan sehari-hari disekitar peserta didik.

Keefektifan penggunaan buku siswapada keterampilan kreatif dan inovasi dilihat berdasarkan hasil angket dari indikator-indikator keterampilan kreatif dan inovasi dilihat pada Gambar 3. Buku siswa efektif jika terdapat pengaruh buku siswa IPA Terpadu men ingkatkan keterampilan abad 21 terhadap peningkatan keterampilan kreatif dan inovasi peserta didik dalam proses pembelajaran.

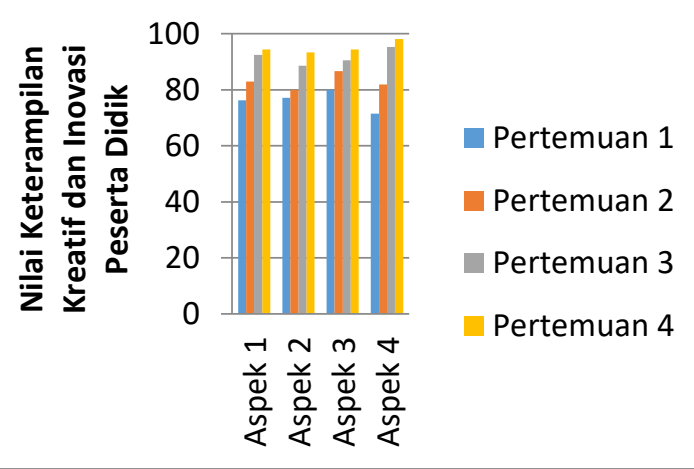

Gambar 3. Rekapitulasi Hasil Penilaian Keteram pilan Kreatif dan Inovasi Peserta Didik Setiap Pertemuan

Keterangan : Aspek 1 : Orisinalitas; Aspek 2 : Kelancaran; Aspek 3 : Kelenturan; Aspek 4 : Elaborasi.

Penilaian keterampilan kreatif dan inovasi yang diperoleh peserta didik untuk setiap pertemuan memiliki rata-rata dalam kategori baik yaitu pada pertemuan 1, pertemuan 2, pertemuan 3 dan 4 berada dalam kategori sangat baik. Setelah ujicoba dilakukan nampak bahwa nilai penilaian keterampilan kreatif dan inovasi mengalami kenaikan dari pertemuan pertama 
sampai pertemuan terakhir. Hal ini berarti ratarata keterampilan kreatif dan inovasi yang dimiliki peserta didik setelah belajar meng gunakan buku siswa IPA Terpadu sudah baik. Artinya setelah melakukan pembelajaran dengan buku siswa, peserta didik rata-rata telah memili ki keterampilan kreatif dan inovasi selama proses pembelajaran dikelas.

Penilaian keterampilan berkomunikasi serta keterampilan kolaborasi dinilai pada setiap pertemuan. Berdasarkan Gambar terjadi peningkatan keterampilan berkomunikasi dan kolaborasi pada setiap pertemuan. Hal ini disebabkan, karena Buku siswa IPA Terpadu melatih siswa berkomunikasi dengan baik dalam setiap materi yang di pelajari dan langkah langkah kegiatan peserta didik yang memvantu peserta didik saling berinteraksi dan kerjasama, sehingga peserta didik terlatih berkomunikasi dengan bai dan tak terbatas, percaya diri dalam penyampaian pendapat serta berkerjasama baik dengan teman-temannya.

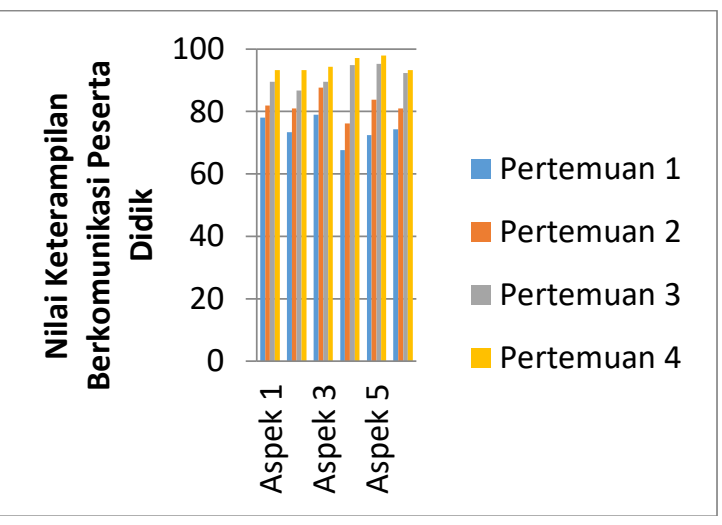

Gambar 4. Rekapitulasi Hasil Penilaian Keteram pilan Berkomunikasi Peserta Didik Setiap Pertemuan

Keterangan : Aspek 1 :Menghubungkan benda nyata, gambar, dan diagram kedalam ide pembelajaran; Aspek 2 :Menginterpretasikan dan mengevaluasi ide-ide, symbol, istilah serta informasi dalam pembelajaran; Aspek 3 : Menje laskan ide, situasi dan relasi secara lisan atau tulisan dengan benda nyata, gambar, grafik dan aljabar ; Aspek 4 :Menggunakan alur pikir yang logis, terstruktur sesuai dengan kaidah yang berlaku; Aspek 5 : Membuat konjectur, menyu sun argumen, merumuskan definisi dan genera lisasi; Aspek 6 :Berkomunikasi tidak terbatas hanya pada satu bahasa, tetapi multibahasa.
Penilaian keterampilan kolaborasi siswa yang dilakukan pada SMP Negeri 1 Sijunjung dapat dilihat dari Gambar 5.

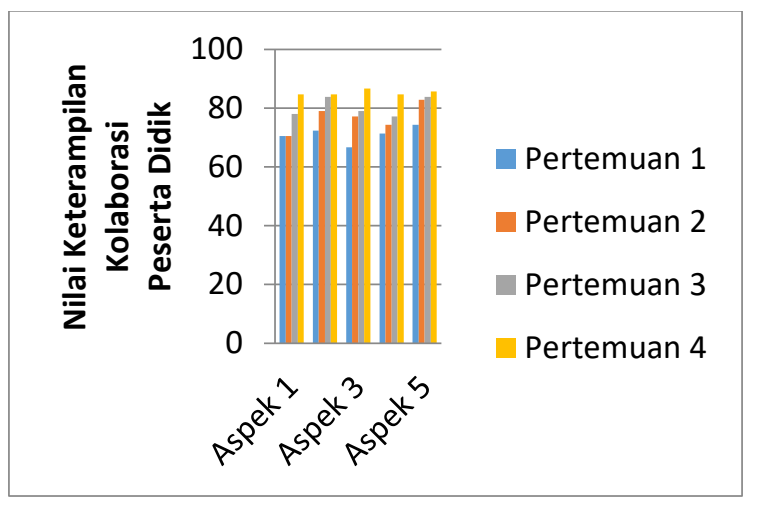

Gambar 5. Rekapitulasi Hasil Penilaian Keteram pilan Kolaborasi Peserta Didik Setiap Pertemuan

Keterangan : Aspek 1 :Konstribusi; Aspek 2 : Manajemen Waktu; Aspek 3: Pemecahan Masa lah; Aspek 4 : bekerjasama dengan orang lain; Aspek 5: Teknik Penyelidikan.

Peningkatan keterampilan kolaborasi peserta didik pada setiap pertemuan dapat dilihat pada Gambar 5. Perubahan keterampilan yang positif ditunjukkan oleh sebagian besar siswa disekolah. Hasil dari nilai keterampilan kolabo rasi pada kelas VII 1 SMP Negeri 1 Sijunjung berada pada kategori baik.

Efektivitas buku siswa dilihat berdasarkan hasil angket dari indikator-indikator pada satu kelas. Dua perlakuan dilakukan dalam satu kelas yakni sebelum dan sesudah melakukan perlaku an. Untuk melihat keefektifan buku siswa terse but dilihat apakah terjadi peningkatan keteram pilan abad 21 pada peserta didik. Untuk keteram pilan abad 21 ada 4 paramater yaitu keteram pilan berpikir kritis dan pemecahan masalah, keterampilan kreatif dan inovasi, keterampilan berkomunikasi dan keterampilan kolaborasi.

Keterampilan berpikir kritis dan peme cahan masalah dinilai pada setiap pertemuan. Berdasarkan Gambar 2, terjadi peningkatan keterampilan berpikir kritis dan pemecahan masalah pada setiap pertemuan. Hal ini disebabkan, karena buku siswa IPA Terpadu tipe integrated dengan tema energi dalam kehidupan berbasis materi local daerah Sijunjung untuk meningkatkan keterampilan abad 21 berisikan materi berbasis Materi Lokal dengan penguatan adanya soal dan kegiatan siswa, sehingga peserta didik terlatih dan membantu meningkatkan keterampilan berpikir kritis. 
Materi Lokal yang disajikan pada buku siswa adalah materi lokal yang berada pada daerah Sijunjung, Kabupaten Sijunjung, Sumatera Barat. Materi Lokal yang ambil berupa kaarifan lokal daerah dari daerah tersebut. Mulai dari kegiatan masyarakat, makanan, tempat wisata sampai bencana yang ada kemudian dimasukkan kedalam Buku Siswa IPA Terpadu tipe integrated agar pembelajaran peserta didik lebih bermakna, karena pembe lajaran terkait dengan kehidupan sehari- hari disekitar peserta didik. Berikut ini contoh Materi Lokal daerah Sijunjung yang di padukan keda lam buku siswa IPA Terpadu. Materi Lokal pada buku siswa ini dapat dilihat pada Gambar 6.

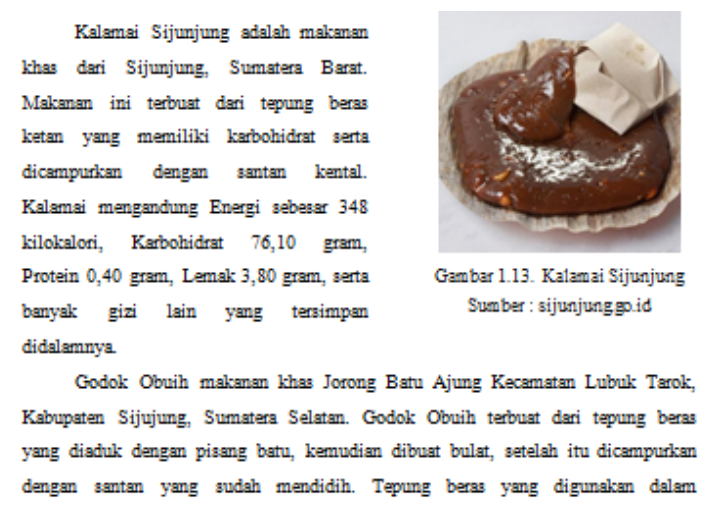

(a)

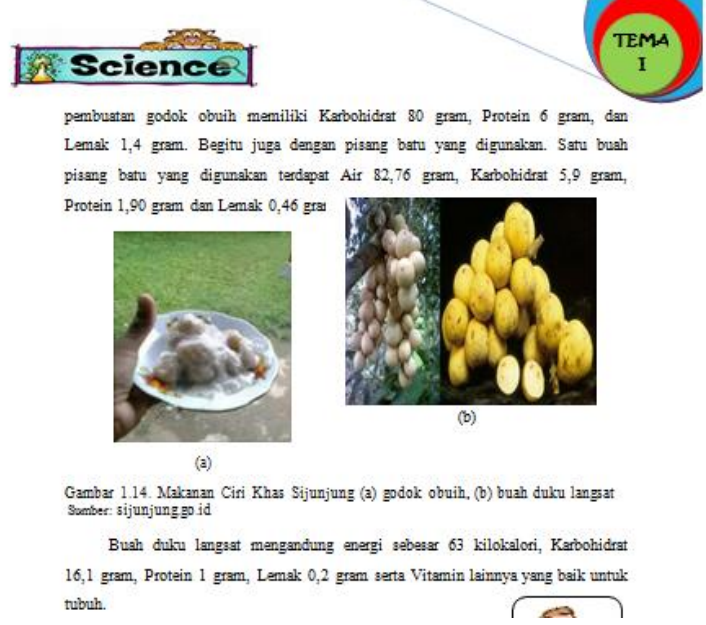

(b)

Gambar 6. Materi lokal daerah Sijunjung (a) Kalamai Sijunjung, dan (b) Godok Obuih dan Buah Langsek Sijunjung

Keefektifan penggunaan buku siswa pada keterampilan kreatif dan inovasi dilihat pada Gambar 3. Buku siswa efektif jika terdapat pengaruh buku siswa IPA Terpadu tipe integrated untuk meningkatkan keterampilan abad 21 terhadap peningkatan keterampilan kreatif dan inovasi peserta didik dalam proses pembelajaran.

Penilaian keterampilan berkomunikasi serta keterampilan kolaborasi dinilai pada setiap pertemuan. Berdasarkan Gambar 4 dan 5, terjadi peningkatan keterampilan berkomunikasi dan kolaborasi pada setiap pertemuan. Hal ini disebabkan, karena buku siswa IPA Terpadu tipe integrated untuk meningkatkan keterampilan abad 21 berisikan multibahasa dalam setiap materi berbasis materi lokal yang disajikan dan langkah - langkah kegiatan peserta didik yang membantu peserta didik saling berinteraksi dan kerjasama, sehingga peserta didik terlatih multibahasa, percaya diri dalam penyampaian pendapat serta berkerjasama baik dengan temantemannya.

Sejalan dengan penelitian yang telah dilakukan sebelumnya, buku siswa IPA Terpadu tipe integrated untuk meningkatkan keteram pilan abad 21diharapkan dapat meningkatan keterampilan abad 21 peserta didik dalam menghadapi tantangan global. Materi lokal daerah Sijunjung yang diperoleh melalui proses belajar mengajar dapat memberikan pengeta huan yang lebih kepada siswa. Proses belajar mengajar pada peserta didik dapat membantu meningkatkan keterampilannya dan bisa menerapkannya dalam kehidupan, maksudnya peserta didik tidak hanya diharapkan mampu memahami materi tetapi materi yang diajarkan dapat diaplikasikan dalam kehidupan peserta didik. Pembelajaran melalui buku siswa IPA Terpadu tipe integrated initelah efektif benarbenar dapat membantu peserta didik dalam meningkatkan keterampilan abad 21 peserta didik dalam menghadapi tantangan global.

\section{KESIMPULAN}

Artikel ini telah dipresentasikan dengan judul penelitian pengembangan buku siswa IPA Terpadu ini dapat meningkatkan kecakapan abad 21. Buku siswa ini telah efektif untuk digunakan dalam meningkatkan keterampilan abad 21 peserta didik yaitu keterampilan berpikir kritis dan pemecahan masalah, kreatif dan inovatif, berkomunikasi dan keterampilan kolaborasi.

\section{DAFTAR PUSTAKA}

Abd. Kadir. (2014). Pembelajaran Tematik. Jakarta: Raja Grafindo Persada.

Alfian, Magdalia. (2013). Peranan Kearifan Lokal dalam Pembentukan Jati Diri dan 
Karakter Bangsa. Prosiding The 5 thn ICSSIS; Ethnicity and Globaliation (2013). Yogyakarta.

Arikunto, Suharsimi. 2010. Dasar-Dasar Evaluasi Pendidikan. Bumi Aksara: Yogyakarta.

Azwar, Saifuddin.(2013). Sikap Manusia: Teori dan Pengukurannya. Yogyakarta: Pustaka Pelajar.

Direktorat Pendidikan Dasar dan Menengah. (2017). Implementasi Pengembangan Kecakapan Abad 21 dalam Perencanaan Pelaksanaan Pembelajaran (RPP). Jakarta : Ditjen.

Fajarini, Ulfah. (2014). Peranan Kearifan Lokal dalam Pendidikan Karakte. Jurnal Sosio Diaktika; Vol.1, No.2.

Fogarty, Robin. (1991). How to Integrated the Curricula. Palatine, Ilinois: IRI/ Skylight Publishing, Inc.

Fogarty.(1991). Ten ways to integrate curiculum. Palatine Illinois: IRI/Skylight Publishing, Inc.

Hidayat, Zaitul.(2019). Analysis of learning media in developing science textbooks with theme energy in life using integrated model for integrated 21st century learning. IOP Conf. Series: Journal of Physics: Conf. Series 1185 (2019) 012070
Hidayat, Zaitul.(2019). Practicality of Science Student Books with the Theme of Energy in Life Based Integrated Local Materials Using Integrated Models for 21 st Century Learning. International Journal of Progressive Sciences and Technologies (IJPSAT). ISSN:2509-0119.Vol 16 No.2 September 2019, pp.183-19.

Kementerian Pendidikan dan Kebudayaan. (2013). Kompetensi Dasar Sekolah Menengah Atas. Jakarta : Kementerian Pendidikan dan Kebudayaan.

Kemendikbud. (2013). Permendikbud Nomor $81 A$ Tahun 2013 tentangImplementasi Kurikulum. Jakarta. BSNP.

Plomp, T. (2013). Educational and Training System Design. Enschede. Univercity of Twente: Netherlands.

Prastowo A.(2013).Pengembangan Bahan Ajar Tematik. Yogyakarta: Diva Press.

Riduwan. (2009). Belajar Mudah Penelitian Untuk Guru-Karyawan dan Peneliti Pemula. Bandung: Alfabeta.

Sitepu. 2015. Penulisan Buku Teks Pelajaran. Jakarta : Rosda Karya.

Sugiyono. 2011. Metode Penelitian Pendidikan Pendekatan Kuantitatif, Kualitatif dan $R$ \& D. Bandung: Alfabeta. 